\title{
DETERMINANTS OF THE PERCEIVED INTERNSHIP EFFECTIVENESS: EXPLORING STUDENTS' EXPERIENCES
}

\author{
Diana IVANA* \\ Babeș-Bolyai University, Romania
}

\begin{abstract}
Internships are increasingly important for the business higher education as they help students to make the connection between their academic studies and the world of business. This study analyzes the internships of students within an international study program (German line of study) in order to determine what factors account for the most valuable internship experience. Based on the elements of the experiential education approach, the results reveal some characteristics that contribute to a higher level of perceived internship effectiveness in accordance with the employment status and gender. These results provide a basis for designing successful internship programs in business universities.
\end{abstract}

JEL classification: I23, J24

Keywords: Internship Effectiveness, Experiential Education, Personal and Academic Impact.

\section{Introduction}

Internships have been introduced in many of the universities around the world as there is a common understanding that it will help prepare students to enter the workforce. Moreover, the benefits brought by internships are two fold. According to Cheong, Yahya, Shen and Yen Yen (2014), internships also provide companies with potential recruits. As interns/ students are the main beneficiars of the internships, their feedback is crucial in ensuring that the entire program meets the expectations.

The paper firstly discusses the importance of the internships among business students and explains how the experiential education contributes to the perceived effectiveness of the internships. Then, the case study presented in the paper aims to explore students' experience and perception of participating in

\footnotetext{
* Corresponding author. Address: Babeș-Bolyai University, Romania, Faculty of Economics and Business Administration, Str. Teodor Mihali, Nr. 58-60, 400591, Cluj-Napoca, Romania, Tel: +40 264-41.86.55, E-mail: diana.ivana@econ.ubbcluj.ro
} 
internship programs within an international study program (German line). As internship experiences were considered as valuable experiences for undergraduate students, their perceptions may well reflect the outcomes of the program.

By highlighting the main determinants of the perceived internship effectiveness by employment status and gender, the paper illustrates some aspects that are perceived by the students as being more effective for them after completing the internship program. Moreover, the exploration into students' perceptions would enhance our understanding of the internship experiences and therefore benefit from the development of appropriate internship programs.

\section{Literature Review}

Despite the growing popularity of internships in Romania surprisingly little research has been done regarding its perceived effectiveness and the experiential education as most studies were performed regarding the internship quality within the study programs.

For example, a study performed in 2018 in the most extended Business Administration University in Romania aims to identify and analyze the main factors which influence the quality of an internship program from Romanian business and administration students' perspective. The results show that there exist 5 key factors influencing the quality of internship: job arrangements, mentorship and employability benefits, learning content, academic supervision, bureaucracy, and accessibility. The survey provides good insights for companies and universities about the quality dimensions of internship programs in the economic area (Marinas, et al., 2018).

Thus, the literature on business school internships is scant, it lacks a dominant theoretical perspective and is mostly descriptive in most empirical studies (Narayanan and Olk 2010). Although internship programs involve a complex relationship between students, faculty staff, and companies, most research is traditionally focused only on a small part of the overall process and mainly on the perceived quality. Therefore, we attempt to address these gaps as follow.

Actually, in Romania there are no studies addressing the determinants of perceived effectiveness of internship in accordance with the experiential education. As business teachers we have been involved in the tutorial activities of the internship programs and also have the possibility to supervise this program directly from the company by means of the practical experience we gained in the last 3 years.

Therefore, the paper provides an analysis of the main determinants of the internship effectiveness by taking into consideration five dimensions of experiential education: personal, interpersonal, academic, employment and civic impact. The study has also an informative role as it provides valuable information for the companies in order to assess attractive internship programs and help students to find a job after finishing the studies. After performing the internship programs, the university representatives had some discussions with the core companies and there were implemented some improvement measures and also designed further plans for the next internship program. In this context, one could mention that internships provide new recruitment opportunities for the employers and HR, as they have the possibility to evaluate interns in order to access new skills and talent in a costeffective way and to bring in the companies one of the best entry-level employees (Knemeyer, Murphy, 2002). 
The main reason why such a study is beneficial for the universities, students and companies is that students actually ranked internships as the most important contributors to their learning and consequently to their future career development (Karns, 2005). The research shows that there are numerous experiences a student can engage in during the internship, that could result in the student perceiving the internship as a satisfying and worthwhile experience. Moreover, internships seem to close the gap between learned theory and practical reality and are often the first opportunity for many students to obtain meaningful field experience in their area of study (Koo, Diacin, Khojasteh, Dixon, 2016).

A supplement of theoretical education helps the students to gain new skills and experiments in practice and to reach the relevant field of business (Abrudan, Lazar, Munteanu, 2012). The internship is an important way through which students need to get to know the business world by working in it and to implement the information they acquired during their theoretical education (Seyitoglu and Yirik, 2015).

Universities and colleges have been using internships in order to provide business students with practical experiences and prepare them for their future careers (Moghaddam, 2011).

Martin and Wilkerson's (2006) performed a study on 132 accounting students and the research shows that the students agreed that their internship provided them with a solidified understanding of prior academic work, beneficial for subsequent academic work, provided them with new insights into courses and improved understanding of concepts (Cheong, Yahya, Shen and Yen Yen, 2013).

Referring to findings of various studies, one could mention that there exist four career preparation skill categories: communication skills, academic skills, interpersonal skills, and job acquisition skills. An effective internship program should be able to provide and/or enhance such skills and prepare students to face real life challenges after their graduation (Moghaddam, 2011).

Further, the variations among the terms used to describe outside-the-classroom learning opportunities can be condensed into one phrase: experiential education. It is well known that this kind of experiential education includes potential experiences, including self-learning internships, academic service learning, community service learning, cooperative education programs and applied practice (Jackel, 2011).

Therefore, research suggests, that an experiential education learning outcomes are categorized into five sections: personal, interpersonal, academic, employment and civic impact (Raman and Pashupati, 2010, Jackel, 2011). The questionnaire in this study is designed by taking into consideration all the above-mentioned dimensions, but only two of them are analyzed in this paper: personal and academic outcome.

Personal outcomes are focused on individual thoughts, skills and values. A study quoted in (Jackel, 2011) found that students who participated in applied learning programs had greater volunteer motivation and moral development than students who did not participate. In this context, Androniceanu (2013) highlights that the absorption of ethical values depends on the work environment, organizational culture, and the particular characteristics of the human resources. In addition to exposure to the real-life business practices and cultures, one's personality traits (characteristics) may also impact his/her personal/business values.

Academic outcomes concentrate on the educational achievement and knowledge gained from the applied learning experience. Some researchers found that students who participated in an applied learning program received higher grades 
than students who only receive the classroom instructions (Markus, Howard, and King 1993, Jackel, 2011). Therefore, internships provide learning opportunities for students to experience professional practice and activities related to the application of knowledge (Beggs, Ross, and Goodwin, 2008, Velez and Giner, 2015).

Taking into consideration that the internship program takes places in an international study program, in addition to the before mentioned benefits, internships in an international environment plays a pivote role in improving intercultural competencies. Intercultural competence includes three basic aspects: intercultural communicative skills, intercultural work experience and intercultural understanding. These three aspects appear to be improved through the experience of an international internship (Zhang, 2012).

Hergert (2009) discovers that a valuable internship was influenced by students' perceived value, demographic profile and the structure of the internship. Therefore, this paper evaluates the perception of personal and academic outcome in accordance with some demographical variables such as gender and employment status.

Finally, according to Narayanan and Olk (2010), internship experiences can overcome presumed shortcomings such as the lack of specific preparation, sometimes called "deficit reduction theory", Also, beyond skills training, internships also help socialize and acculturate, they improve career decision making and perceptions of self-efficacy.

\section{Methodology}

The current paper is divided into two sections. The first section presents the methodological research design and survey instrument and the second section discusses the data analysis and results.

\subsection{Research Methodology and Measuring instrument}

Based on the review and synthesis of relevant literature, this paper measures the determinants of internship effectiveness within an international study program at the German line of study. Therefore, there was designed a questionnaire based on the topic of experiential education (Jackel, 2011) and sent to the students at the German line of study, that performed the internship program. It is remarkable, that depending on the specialization, the students could perform the internship program either in the Business Administration Area (for the Bachelor students) or Economy of International Companies Area (for the Master students). The curriculum was designed so that one could perform the internship in one of the business support function departments within a company such as: HR, controlling, marketing, finance, Quality Management or legal. The curriculum has a defined structure but depending on the department, the students could perform the task they receive. Actually, research indicates the curriculum promotes the ability of the students to achieve one of the beneficial goals for them, namely to understand their lives and the extreme complexities of social organizations (Parilla \& Hesser, 1998).

In order to asses the effectiveness of the internship program, a mixed method was implemented by using both qualitative and quantitative approaches. The survey was developed according to Jackel Daniel (2011) via E-mail to the respondents. 
Before the survey distributions, the researchers conducted a focus group of 20 students in order to identify improvement areas. Some of the questions were reformulated and adapted to the internship program for the German Line.

A total number of 143 respondents completed the questionnaire $(N=143)$ and the response rate was $70.4 \%$ (of the total number of 203 students that could perform the internship programs within the analyzed international study programs).

By analyzing the students' demographic structure, one can confirm that a significative number of the students were employed after this experience.

Nevertheless, most internships were not only in the Economic field, but also in the IT consultancy area, which is explained by the good cooperation the faculty has with the companies in this domain:

Table 1: Demographic characteristics of the respondents in the sample

\begin{tabular}{|l|l|}
\hline \multicolumn{1}{|c|}{ Demographic Variables } & \multicolumn{1}{l|}{ Results } \\
\hline Gender & $74.1 \%$ \\
\hline Female & $25.9 \%$ \\
\hline Male & $80.4 \%$ \\
\hline Internship Area & $19.6 \%$ \\
\hline Economics \\
\hline IT Consultancy & $51.7 \%$ \\
\hline Employment Status & $48.3 \%$ \\
\hline Employed &
\end{tabular}

Further, the questionnaire contains two main parts: the first part divided in five sections refers to the characteristics of the experiential education and the second section presents the demographic background of the students.

The five sections in the first part of the questionnaire include categories like: personal, interpersonal, academic, occupational and civic characteristics. Each of these sections presents five to eight statements that gave certain attributes supposed to be gained during the internship program. The respondents should use a five-point Likert scale in order to indicate the degree to which the internship program increased their abilities in each area.

The second part contains background information about the respondents such as those presented in Tabel 1: gender, employment status, internship area, but also some qualitative information about the improvement area that further programs should take into consideration in order to increase internship effectiveness.

The independent variables in this study refer actually to these background characteristics namely the articles focuses on employment status and gender. The dependent variables taken into consideration in this paper is indicated by the personal impact and academic impact dimensions. Regarding these specific variables' influence on the predicted learning outcomes, the following research model was proposed:

$\mathrm{H} 1$ : there exist determinants of the perceived internship effectiveness, which differ in accordance with the employment status.

$\mathrm{H}$ 2: there exist determinants of the perceived internship effectiveness, which differ in accordance with the gender. 


\subsection{Data analysis and results}

In order to highlight those characteristics that set a higher level of effectiveness in accordance with the employment status and gender, there was used as a statistical method the independent samples t-test with SPSS. The test is used to compare the means between two unrelated groups on the same continuous, dependent variable:

$$
t=\frac{\bar{x}_{1}-\bar{x}_{2}}{s_{p} \sqrt{\frac{1}{n_{1}}+\frac{1}{n_{2}}}}
$$

with

$$
s_{p}=\sqrt{\frac{\left(n_{1}-1\right) s_{1}^{2}+\left(n_{2}-1\right) s_{2}^{2}}{n_{1}+n_{2}-2}}
$$

According to Table 2 -Table 5, the Levene's Test for Equality of Variances and the independent samples test indicates that there are some characteristics of the internship program, there were perceived as more effective.

For the first hypothesis, these characteristics bring to the fore personal aspects like: the satisfaction in doing something worthwhile, the ability to make a difference, the capacity to be more productive, the ability to identify personal strengths, the sense of personal achievement and the ability to persevere in difficult tasks.

In other studies the dimension of personal impact was correlated with the number of hours worked weekly at placement site, internship paid (yes), preparation/ training (yes), and availability of internship program coordinator (Jackel, 2011). Therefore, related to the personal impact one of the most important features of internships should be the one that gives the students the possibility to see through personal learning experience what working in a certain company environment really entails (Hurst, Good,2010).

Table 2: Independent Samples Test for the independent variable Employment

\begin{tabular}{|c|c|c|c|c|c|c|c|c|c|}
\hline & \multicolumn{2}{|c|}{$\begin{array}{l}\text { Levene's Test } \\
\text { for Equality of } \\
\text { Variances }\end{array}$} & \multicolumn{7}{|c|}{ t-test for Equality of Means } \\
\hline & \multirow[t]{2}{*}{$\mathbf{F}$} & \multirow[t]{2}{*}{ Sig. } & \multirow[t]{2}{*}{$t$} & \multirow[t]{2}{*}{ df } & \multirow[t]{2}{*}{$\begin{array}{c}\text { Sig. } \\
\text { (2-tailed) }\end{array}$} & \multirow[t]{2}{*}{$\begin{array}{c}\text { Mean } \\
\text { Difference }\end{array}$} & \multirow[t]{2}{*}{$\begin{array}{l}\text { Std. Error } \\
\text { Difference }\end{array}$} & \multicolumn{2}{|c|}{$\begin{array}{l}\text { 95\% Confidence } \\
\text { Interval of the } \\
\text { Difference }\end{array}$} \\
\hline & & & & & & & & \begin{tabular}{|l|} 
Lower \\
\end{tabular} & Upper \\
\hline \multirow{2}{*}{$\begin{array}{l}\text { I have a sense } \\
\text { of satisfaction } \\
\text { in doing } \\
\text { something } \\
\text { worthwhile }\end{array}$} & .706 & .402 & -.944 & 141 & .347 & -.121230 & .128462 & -.375191 & .132731 \\
\hline & & & -.943 & 140.008 & .347 & -.121230 & .128524 & -.375329 & .132869 \\
\hline \multirow{2}{*}{$\begin{array}{l}\text { I believe in my } \\
\text { ability to make } \\
\text { a difference }\end{array}$} & .408 & .524 & -.864 & 141 & .389 & -.12143 & .14049 & -.39917 & .15632 \\
\hline & & & -.861 & 136.806 & 391 & -.12143 & .14101 & -.40028 & .15742 \\
\hline
\end{tabular}
Status and Personal Impact 


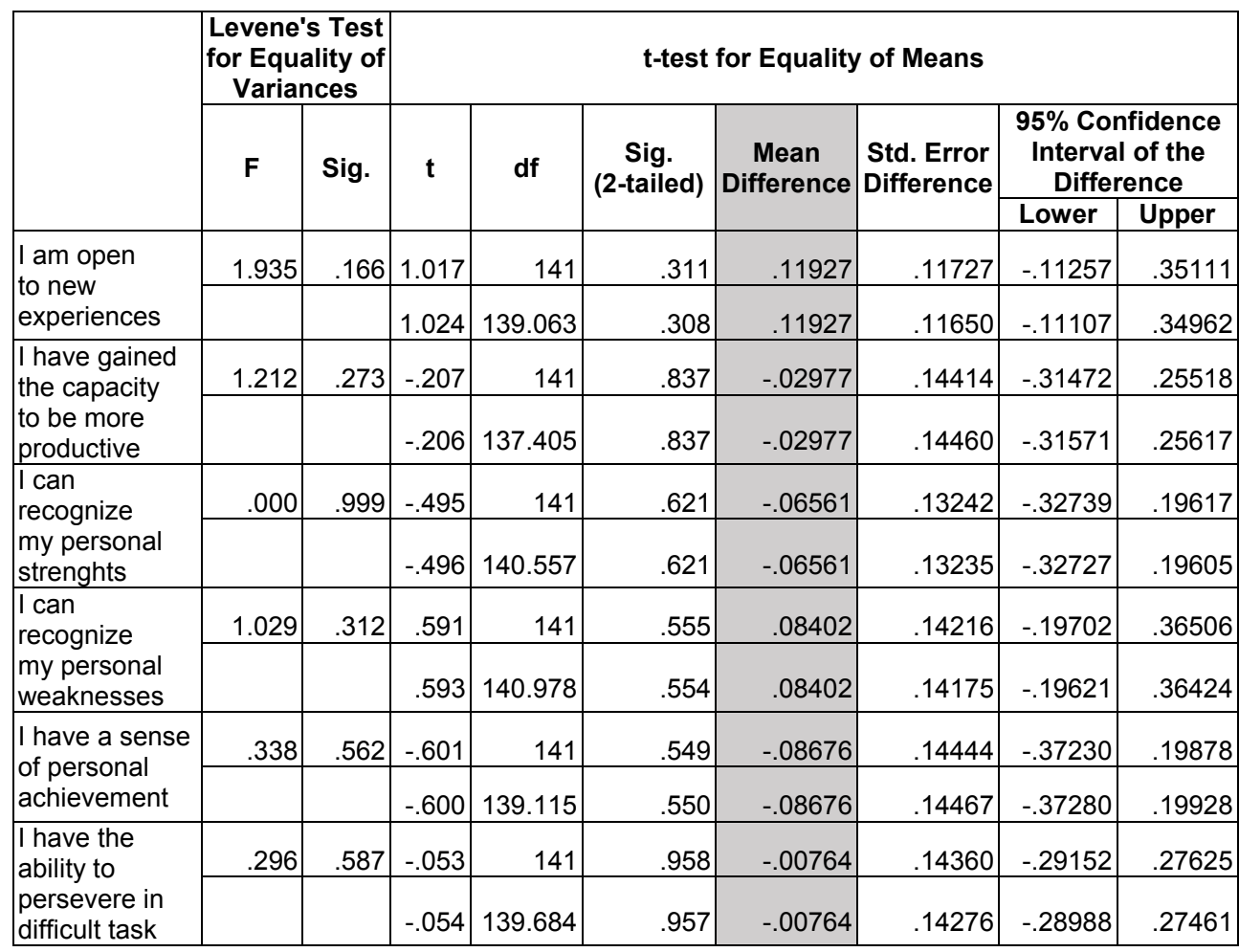

The academic impact highlights the following characteristics: the acquired knowledge, the development of critical thinking (reasoning, problem- solving) and the perception that after the internship program the classroom learning was enriched.

Table 3: Independent Samples Test for the independent variable Employment Status and Academic Impact

\begin{tabular}{|c|c|c|c|c|c|c|c|c|c|}
\hline & \multicolumn{2}{|c|}{$\begin{array}{c}\text { Levene's Test } \\
\text { for Equality of } \\
\text { Variances } \\
\end{array}$} & \multicolumn{7}{|c|}{ t-test for Equality of Means } \\
\hline & \multirow[t]{2}{*}{ rania } & \multirow[t]{2}{*}{ Sig. } & \multirow[t]{2}{*}{$\mathbf{t}$} & \multirow[t]{2}{*}{ df } & \multirow{2}{*}{$\begin{array}{c}\text { Sig. } \\
(2- \\
\text { tailed })\end{array}$} & \multirow[t]{2}{*}{$\begin{array}{c}\text { Mean } \\
\text { Difference }\end{array}$} & \multirow[t]{2}{*}{$\begin{array}{l}\text { Std. Error } \\
\text { Difference }\end{array}$} & \multicolumn{2}{|c|}{$\begin{array}{l}95 \% \text { Confidence } \\
\text { Interval of the } \\
\text { Difference }\end{array}$} \\
\hline & & & & & & & & Lower & Upper \\
\hline \multirow{2}{*}{$\begin{array}{l}\text { I have acquired } \\
\text { knowledge form } \\
\text { the job duties } \\
\text { I performed }\end{array}$} & .724 & .396 & -.114 & 141 & .909 & -.01723 & .15088 & -.31551 & .28104 \\
\hline & & & -.115 & 140.678 & .909 & -.01723 & .15025 & -.31428 & .27981 \\
\hline \multirow{2}{*}{$\begin{array}{l}\text { have } \\
\text { developed my } \\
\text { critical thinking } \\
\text { (reasoning, } \\
\text { problem solving) }\end{array}$} & .325 & .569 & -.542 & 141 & .589 & -.07814 & .14426 & -.36334 & .20705 \\
\hline & & & -.542 & 140.170 & .589 & -.07814 & .14429 & -.36342 & .20713 \\
\hline
\end{tabular}




\begin{tabular}{|c|c|c|c|c|c|c|c|c|c|}
\hline & \multicolumn{2}{|c|}{$\begin{array}{c}\text { Levene's Test } \\
\text { for Equality of } \\
\text { Variances } \\
\end{array}$} & \multicolumn{7}{|c|}{ t-test for Equality of Means } \\
\hline & \multirow[t]{2}{*}{$\mathbf{F}$} & \multirow[t]{2}{*}{ Sig. } & \multirow[t]{2}{*}{$\mathbf{t}$} & \multirow[t]{2}{*}{ df } & \multirow{2}{*}{$\begin{array}{c}\text { Sig. } \\
(2- \\
\text { tailed })\end{array}$} & \multirow[t]{2}{*}{$\begin{array}{c}\text { Mean } \\
\text { Difference }\end{array}$} & \multirow[t]{2}{*}{$\begin{array}{l}\text { Std. Error } \\
\text { Difference }\end{array}$} & \multicolumn{2}{|c|}{$\begin{array}{l}95 \% \text { Confidence } \\
\text { Interval of the } \\
\text { Difference }\end{array}$} \\
\hline & & & & & & & & Lower & Upper \\
\hline \multirow{2}{*}{$\begin{array}{l}\text { I have the ability } \\
\text { to work and } \\
\text { learn } \\
\text { independently }\end{array}$} & 2.926 & .089 & 1.111 & 141 & 268 & .14414 & .12969 & -.11225 & .40054 \\
\hline & & & 1.109 & 138.687 & .269 & .14414 & .12996 & -.11282 & .40111 \\
\hline \multirow{2}{*}{$\begin{array}{l}\text { I feel my } \\
\text { classroom } \\
\text { learning was } \\
\text { enriched }\end{array}$} & 2.764 & .099 & -.111 & 141 & .912 & -.01880 & .16888 & -.35267 & .31507 \\
\hline & & & -.111 & 133.603 & .912 & -.01880 & .16987 & -.35479 & .31719 \\
\hline
\end{tabular}

Regarding the independent variable gender (Table 4) it is remarkable, that female respondent tends to perceive more effective personal aspects like: they are open to new experiences, the capacity to be more productive, the sense of personal achievement, the ability to identify personal weaknesses and the ability to persevere in difficult tasks.

Table 4: Independent Samples Test for the independent variable Gender and Personal Impact

\begin{tabular}{|c|c|c|c|c|c|c|c|c|c|}
\hline & \multicolumn{2}{|c|}{\begin{tabular}{|c|} 
Levene's Test \\
for Equality of \\
Variances \\
\end{tabular}} & \multicolumn{7}{|c|}{ t-test for Equality of Means } \\
\hline & \multirow[t]{2}{*}{$\mathbf{F}$} & \multirow[t]{2}{*}{ Sig. } & \multirow[t]{2}{*}{$\mathbf{t}$} & \multirow[t]{2}{*}{ df } & \multirow{2}{*}{$\begin{array}{l}\text { Sig. } \\
(2- \\
\text { tailed) }\end{array}$} & \multirow[t]{2}{*}{$\begin{array}{c}\text { Mean } \\
\text { Difference }\end{array}$} & \multirow[t]{2}{*}{$\begin{array}{l}\text { Std. Error } \\
\text { Difference }\end{array}$} & \multicolumn{2}{|c|}{$\begin{array}{l}\text { 95\% Confidence } \\
\text { Interval of the } \\
\text { Difference }\end{array}$} \\
\hline & & & & & & & & \begin{tabular}{|l|} 
Lower \\
\end{tabular} & Upper \\
\hline \multirow{2}{*}{$\begin{array}{l}\text { I have a sense } \\
\text { of satisfaction } \\
\text { in doing } \\
\text { something } \\
\text { worthwhile }\end{array}$} & .338 & .562 & -2.099 & 141 & .038 & -.303927 & .144793 & -.590173 & -.017680 \\
\hline & & & -2.095 & 62.694 & .040 & -.303927 & .145046 & -.593805 & -.014048 \\
\hline \multirow{2}{*}{$\begin{array}{l}\text { I believe in my } \\
\text { ability to make } \\
\text { a difference }\end{array}$} & .092 & .763 & .265 & 141 & .791 & .04258 & .16069 & -.27509 & .36025 \\
\hline & & & .279 & 69.248 & .781 & .04258 & .15275 & -.26213 & .34729 \\
\hline \multirow{2}{*}{$\begin{array}{l}\text { I am open to } \\
\text { new } \\
\text { experiences }\end{array}$} & 5.174 & .024 & -1.264 & 141 & .208 & -.16879 & .13354 & -.43280 & .09522 \\
\hline & & & -1.125 & 52.271 & .266 & -.16879 & .15008 & -.46990 & .13232 \\
\hline \multirow{2}{*}{$\begin{array}{l}\text { I have gained } \\
\text { the capacity to } \\
\text { be more } \\
\text { productive }\end{array}$} & .071 & .791 & -2.132 & 141 & .035 & -.34523 & .16190 & -.66529 & -.02517 \\
\hline & & & -2.109 & 61.679 & .039 & -.34523 & .16368 & -.67245 & -.01801 \\
\hline \multirow{2}{*}{$\begin{array}{l}\text { I can } \\
\text { recognize my } \\
\text { personal } \\
\text { strenghts }\end{array}$} & .463 & .497 & 1.377 & 141 & .171 & .20678 & .15022 & -.09018 & .50375 \\
\hline & & & 1.573 & 82.911 & .119 & .20678 & .13142 & -.05461 & .46818 \\
\hline \multirow{2}{*}{$\begin{array}{l}\text { I can } \\
\text { recognize my } \\
\text { personal } \\
\text { weaknesses }\end{array}$} & .703 & .403 & -2.286 & 141 & .024 & -.36461 & .15948 & -.67989 & -.04933 \\
\hline & & & -2.224 & 59.930 & .030 & -.36461 & .16394 & -.69256 & -.03666 \\
\hline
\end{tabular}




\begin{tabular}{|c|c|c|c|c|c|c|c|c|c|}
\hline & \multicolumn{2}{|c|}{$\begin{array}{c}\text { Levene's Test } \\
\text { for Equality of } \\
\text { Variances } \\
\end{array}$} & \multicolumn{7}{|c|}{ t-test for Equality of Means } \\
\hline & \multirow[t]{2}{*}{$\mathbf{F}$} & \multirow[t]{2}{*}{ Sig. } & \multirow[t]{2}{*}{$t$} & \multirow[t]{2}{*}{ df } & \multirow{2}{*}{$\begin{array}{l}\text { Sig. } \\
(2- \\
\text { tailed) }\end{array}$} & \multirow[t]{2}{*}{$\begin{array}{c}\text { Mean } \\
\text { Difference }\end{array}$} & \multirow[t]{2}{*}{$\begin{array}{l}\text { Std. Error } \\
\text { Difference }\end{array}$} & \multicolumn{2}{|c|}{$\begin{array}{l}95 \% \text { Confidence } \\
\text { Interval of the } \\
\text { Difference }\end{array}$} \\
\hline & & & & & & & & Lower & Upper \\
\hline \multirow{2}{*}{$\begin{array}{l}\text { I have a sense } \\
\text { of personal } \\
\text { achievement }\end{array}$} & 2.354 & .127 & -.431 & 141 & .667 & -.07114 & .16491 & -.39714 & .25487 \\
\hline & & & -.476 & 76.381 & .636 & -.07114 & .14960 & -.36907 & .22680 \\
\hline \multirow{2}{*}{$\begin{array}{l}\text { have the } \\
\text { ability to } \\
\text { persevere in } \\
\text { difficult task }\end{array}$} & 1.220 & .271 & -.081 & 141 & .936 & -.01326 & .16384 & -.33717 & .31065 \\
\hline & & & -.090 & 77.819 & .929 & -.01326 & .14739 & -.30670 & .28018 \\
\hline
\end{tabular}

Further, the academic impact was rated as effective by female respondents in all the cases (Table 5) and refers to: the acquired knowledge, the development of critical thinking (reasoning, problem-solving), the ability to work in teams and learn independently and the perception that after the internship program the classroom learning was enriched.

Regarding the academic impact of the internship, the literature and empirical studies show that internships are a critical part of students' active engagement of their academic learning and their perceptions should be recognized. Also, according to Moghaddam (2011) internships could have positive responses from students regarding the value of business education and preparation for future careers. In a longitudinal study by Cook, Stokes, and Parker (2015), students reported that an internship helped them to relate classroom theories to the workplace and also to "become more mature individuals".

Table 5: Independent Samples Test for the independent variable Gender and Academic Impact

\begin{tabular}{|c|c|c|c|c|c|c|c|c|c|}
\hline & \multicolumn{2}{|c|}{$\begin{array}{l}\text { Levene's Test } \\
\text { for Equality } \\
\text { of Variances }\end{array}$} & \multicolumn{7}{|c|}{ t-test for Equality of Means } \\
\hline & \multirow[t]{2}{*}{$F$} & \multirow[t]{2}{*}{ Sig. } & \multirow[t]{2}{*}{$\mathbf{t}$} & \multirow[t]{2}{*}{ df } & \multirow{2}{*}{$\begin{array}{l}\text { Sig. } \\
(2- \\
\text { tailed) }\end{array}$} & \multirow[t]{2}{*}{$\begin{array}{c}\text { Mean } \\
\text { Difference }\end{array}$} & \multirow[t]{2}{*}{$\begin{array}{l}\text { Std. Error } \\
\text { Difference }\end{array}$} & \multicolumn{2}{|c|}{$\begin{array}{l}95 \% \text { Confidence } \\
\text { Interval of the } \\
\text { Difference }\end{array}$} \\
\hline & & & & & & & & Lower & Upper \\
\hline \multirow{2}{*}{$\begin{array}{l}\text { I have acquired } \\
\text { knowledge form } \\
\text { the job duties } \\
\text { I performed }\end{array}$} & .030 & .862 & -.359 & 141 & .720 & -.06170 & .17208 & -.40189 & .030 \\
\hline & & & -.350 & 60.160 & .728 & -.06170 & .17650 & -.41473 & \\
\hline \multirow{2}{*}{$\begin{array}{l}\text { I have developed } \\
\text { my critical thinking } \\
\text { (reasoning, } \\
\text { problem solving) }\end{array}$} & .547 & .461 & $\mid-.466$ & 141 & .642 & -.07675 & .16465 & -.40224 & .547 \\
\hline & & & -.489 & 68.951 & .626 & -.07675 & .15685 & -.38966 & \\
\hline \multirow{2}{*}{$\begin{array}{l}\text { I have the ability } \\
\text { to work and learn } \\
\text { independently } \\
\end{array}$} & .007 & .935 & -.879 & 141 & .381 & -.13029 & .14822 & -.42332 & .007 \\
\hline & & & -.888 & 64.058 & .378 & -.13029 & .14673 & -.42342 & \\
\hline \multirow{2}{*}{\begin{tabular}{|l|} 
I feel my \\
classroom learning \\
was enriched
\end{tabular}} & 1.813 & 180 & --.885 & 141 & .378 & -.17007 & .19217 & -.54998 & 1.813 \\
\hline & & & -.972 & 75.760 & .334 & -.17007 & .17499 & -.51861 & \\
\hline
\end{tabular}




\section{Discussions}

Our goal in this paper was to investigate the determinants of internship effectiveness in an international study program. Although there are some characteristics, that define a higher level of effectiveness in accordance with employment status and gender, our understanding of what makes for an effective internship might be limited.

Extant research provides minimal guidance on the determinants of internship effectiveness and this led us to use a complex questionnaire in order to measure students perception on what this means. So our first contribution is to highlight the central ideas in the literature in order to highlight the main determinants of internship effectiveness, including also evidences about international internships and demographic factors.

Further, our second contribution stems from applying a complex questionnaire to the internship participants within an international study program. The questionnaire suggests the importance of capturing information about each of three actors: students, universities and companies in understanding internship effectiveness. The outcomes of independent t-test were quite revealing. These analyses found that there exist some determinants of internship effectiveness that differ in accordance with gender and employment status.

In general, the importance of internships in business faculties are illustrated in some studies that found that the internships enhance the employability of students. Equally, the students who complete internships report higher salaries and higher level of job satisfaction compared with students who do not complete internships (Velez and Giner, 2015).

Our findings confirm that experiential education through personal and academic characteristics influence student perception of internship effectiveness. With regard to the academic impact, previous studies' findings show that the internships are positively correlated with their content and learning outcomes, the contribution of the internships to employability as well as with the management and supervision of internships (Newman et al., 2007).

Also, internships were correlated with better college performance and receiving a job offer (Knouse and Tanner,1999), which explains our findings that such determinants as the acquired knowledge, the development of critical thinking (reasoning, problem-solving), the ability to work in teams and the perception that after the internship program the classroom learning was enriched are perceived more effective.

Further, regarding the personal impact, employers especially value positive and responsible attitudes, professionalism (Zopiatis, 2007), and communication skills (Alpert et al., 2009) and believe that students should be willing and enthusiastic participants. This aspect is highlighted by the perceived effectiveness in this study through dimensions like: the satisfaction in doing something worthwhile, the ability to make a difference, the capacity to be more productive, the ability to identify personal strengths, the sense of personal achievement and the ability to persevere in difficult tasks.

Findings also indicate that the demographical dimensions such as employability and gender may cause in some situations a higher degree of internship effectiveness. Actually, these demographic and background information also help companies in 
order to assess the structure of the internship programs and to see the overall impact and inclusion of these new joiners in the existing department within the company. For example, it is well known that some of the IT companies in Romania, where our students are performing the internship programs, are having much more males employees than females.

Concluding, our study and survey demonstrates that all the three types of effects of business internships on students: those related to the enhancement of employment opportunities, those related to the improvement of skills and competencies, and those related to the effects on career exploration are demonstrated by the results we received. This also are attesting prior search review conducted by Knouse and Fontenot (2008).

Nevertheless, students found that these business internships are effective in helping them to acquire personal and academic values. Therefore, such perceptions are significant in order to further design studies on greater samples, maybe not only within international study programs, but also within the business faculties in Romania.

\section{Conclusions}

Investigating the relationship between determinants of the perceived internship effectiveness and some demographical factors such as employment status and gender, the results highlight that there exist some characteristics, that are perceived more effective. Regarding the personal and academic impact, which improves career decision making and perceptions of self-efficacy, students confirm that internship helped them to be more open, productive and to perform difficult tasks.

The main conclusions of this article are as follows:

1) There exist some determinants of the perceived internship effectiveness that differ in accordance with some demographic factors such as employment status and gender. Actually, there are some determinants of the internship, that are perceived as being more effective by the employed students and also by the females. It is well known that in Romania feminine student population prevails in the field of economic studies and also that internships support strong employment opportunities.

Since narrowing down the career choices is often a result of the type of work performed and working area, the employment enhancement is actually not related to the behavior, but is mainly a result of the environmental stimuli the students is exposed during the placement period. Nevertheless, males students are often more likely than females to experience a greater civic awareness, but females are often more responsive to the academic impact of the internship programs (Jackel, 2011)

2) The personal and academic impact of the internship are two of the essential characteristics of experiential education. Students connecting and applying their academic experiences to internships may increase their opportunities for employment or entrepreneurship (Nicholas, 2016). 
Regarding the personal impact, internship experience is related to higher levels of self-concept crystallization and internship characteristics of task variety, feedback, and opportunities for dealing with people were significantly associated with self-concept crystallization, amount of occupational information and selfefficacy (Brooks et al., 1995).

Taking into consideration these characteristics, there could be designed an internship program that suits not only to students' needs, but also to the actual labor market. In Romania, German speaking students are hunted by companies and prior internships have a great impact on their employability. Actually, the last study performed for the Romanian labor market shows that in 2019 companies will recruit juniors that have performed internships (Report on Romanian Labour Market, 2019, done by hipo.ro). Equally, internship programs contribute to a better understanding of business concepts and knowledge improvement.

Starting from these conclusions, one could also mention, that students benefit from stronger ties with the academic world. Internship programs are also beneficial to higher education institutions, because universities can attract potential students, enhance their reputation and visibility, and strengthen the collaboration between the academic world and companies (Velez and Giner 2015).

Further, this study found that students place a great value on the internship experience and this has to do with their career goals. The value of the internship is also maximized by the professors, that provide appropriate structure and integrate the internship programs with the students' background.

\section{References}

Alpert, F., Heaney, J.-G.,Kuhn, K.-A. L. (2009). Internships in marketing: Goals, structures and assessment-Student, company and academic perspectives. Australasian Marketing Journal, 17, 36-45

Androniceanu A. (2013). Ethical values and the human resources behavior in public management. Administratie si Management Public, 20, 49-61

Abrudan B., Lazar M., Munteanu A. (2012) Internship roles in training and professional development of student. Annals of Faculty of Economics, 1(1), 986-991

Beggs B., Ross, C. M., Goodwin B. (2008) A comparison of student and practitioner perspectives of the travel and tourism internship. Journal of Hospitality, Leisure, Sport \& Tourism Education, 7, 31-39

Brooks. L., Cornelius, A., Greenfield, E., Joseph, R. (1995) The relation of careerrelated work or internship experiences to the career development of college seniors. Journal of Vocational Behavior, 46: 332-349

Cheong A., Yahya N., Shen Q., Yen Yen A. (2014) Internship Experience: An InDepth Interview among Interns at a Business School of a Malaysian Private Higher Learning Institution, Procedia - Social and Behavioral Sciences 123, 333 343

Cook, S.J., Stokes, A., Parker, R. S. (2015) A 20-year examination of the perceptions of business school interns: a longitudinal case study. Journal of Education for Business, 90, 103-110 
Gi-Yong Koo G., Diacin M., Khojasteh J., Dixon A. (2016) Effects of Internship Satisfaction on the Pursuit of Employment in Sport Management, Sport Management Education Journal, 10, 29-42

Hergert M. (2009) Student Perceptions Of The Value Of Internships In Business Education, American Journal of Business Education, 2 (8), 9-14

Hurst, J.L., Good, L.K. (2010) A 20-year evolution of internships: Implications for retail interns, employers and educators. Int. Rev. Retail. Distrib. Consum. Res., $20,175-186$

Jackel D. (2011) Evaluating the Effectiveness of an Internship Program, Master Theses \& Specialist Projects, Paper 1117.

https://digitalcommons.wku.edu/theses/1117/

Karns, G.L. (2005) An update of marketing student perceptions of learning activities: Structure, preferences, and effectiveness. J. Mark. Educ. 27, 163-171

Knemeyer, M.A., Murphy, P.R. (2002) Logistics internships: Employer and Students Perspectives. Int. Journal of Physical Distribution and Logistic Management 32, 135-152

Knouse, S. B., Tanner, J. R., Harris, E. W. (1999) The relation of college internships, college performance, and subsequent job opportunity, Journal of Employment Counseling, 36, 35-43

Knouse, S. B., Fontenot, G. (2008) Benefts of the business college internship: A research review, Journal of Employment Counseling, 45, 61-66

Marinas, C.V., Goia, S.I., Igret, R.S., Marinas, L.E. (2018) Predictors of Quality Internship Programs-The Case of Romanian Business and Administration University Education, Sustainability Journal, 10(12), 4741

Markus, G., Howard, J., King, D. (1993) Integrating community service and classroom instruction enhances learning: Results from an experiment. Educational Evaluation and Policy Analysis, 15(4), 410-419

Martin, D. R., Wilkerson, J. E. (2006) An Examination of the Impact of Accounting Internships on Student Attitudes and Perception, The Accounting Educators' Journal, 16, 129-138

Matthew S. M., Taylor, R. M., Ellis, R. A. (2012). Relationships between students' experiences of learning in an undergraduate internship programme and new graduates' experiences of professional practice. Higher Education: The International Journal of Higher Education and Educational Planning, 64(4), 529542

Moghaddam J.M. (2011) Perceived Effectiveness of Business Internships: Student

Expectations, Experiences, and Personality Traits, International Journal of Management 28 (4), 287-303

Moghaddam J.M. (2014) Impacts of Internships on Students' Personal/Business Values and the Role of Their Personality Traits, The Journal of Global Business Management, 10 (1), 52-60

Narayanan V.K.,OlkP.M. (2010) Determinants of Internship Effectiveness: An Exploratory Model, Academy of Management Learning \& Education, 2010, 9 (1), $61-80$

Newman, B.S., Dannenfelser, P.L., Clemmons, V., Webster, S. (2007) Working to learn: Internships for today's social work students. Journal of Social Work Education, 43, 513-528 
Nicholas, A. J., (2016) Internships: Experiential Learning, Academic Connection and Assessment Faculty and Staff - Articles \& Papers. 61. htps://digitalcommons.salve.edu/fac_staff_pub/61

Parilla, P., Hesser, G. (1998) Internships and the sociological perspective: Applying principles of experiential learning, Teaching Sociology, 26(4), 310-329

Raman P., Pashupati, K. (2002) Turning good citizens into even better ones: The impact of program characteristics and motivations on service-learning outcomes, Journal of Nonprofit and Public Sector Marketing, 10, 187-207

Seyitoglu F., Yirik S. (2015) Internship Satisfaction of Students of Hospitality and Impact of Internship on the Professional Development and Industrial Perception, Asia Pacific Journal of Tourism Research, 20 (1), 1414-1429

Velez G.S., Giner G.R. (2015) Effects of business internships on students, employers and higher education institutions: a systematic review, Journal of employment counseling, 52, 121-130

Zhang X. (2012) Discussion on international internship and intercultural competence from a perspective of higher educational internationalization-A case study of the program Work and Travel USA. Cross-Cultural Communication, 8 , 62-66

Zhao H., Liden R. (2011) Internship: A Recruitment and Selection Perspective Journal of Applied Psychology, 96 (1), 221-22

Zopiatis, A. (2007) Hospitality internships in Cyprus: A genuine academic experience or a continuing frustration? International Journal of Contemporary Hospitality Management, 19, 65-77 